\title{
Evaluation of knowledge levels about dental trauma (avulsion) and treatment approach of the students of medicine and dentistry faculties
}

\author{
@Simge Gümüş, @Elif Pınar Bakır \\ Dicle University, Faculty of Dentistry, Department of Restorative Dentistry, Diyarbakır, Turkey
}

Cite this article as: Gümüş S, Bakır EP. Evaluation of knowledge levels about dental trauma (avulsion) and treatment approach of the students of medicine and dentistry faculties. J Health Sci Med 2022; 5(1): 207-215.

\begin{abstract}
Aim: In this study aimed to evaluate the knowledge of 4th and 5th grade students of Dicle University Faculty of Medicine and Dentistry and their approach to first intervention in the face of avulsion, which is the one of the types of dentoalveolar injuries.

Material and Method: 300 students selected by random sampling method among 4th and 5th grade students of Dicle University Faculty of Medicine and Dentistry. 17 questions and a questionnaire consisting of three parts were applied to the total of three hundred students from two faculties. The data obtained in this study were analyzed with IBM SPSS 21 package program. While interpreting the results, 0.05 was used as the significance level.

Results: There is a statistically significant relationship between the faculty and the previous trauma/emergency or first aid course status $(\mathrm{p}<0.05)$. While $34 \%$ of the medical school and $86.67 \%$ of the dental students had not taken a trauma/emergency or first aid course before, $66 \%$ of the medicine faculty and $13.33 \%$ of the dentistry faculty have previously taken a trauma/ emergency or first aid course. There is a statistically significant correlation between gender and previous trauma/emergency or first aid course status $(\mathrm{p}<0.05)$. While $76.64 \%$ of women and $51.3 \%$ of men had not taken traum /emergency or first aid courses before; $23.36 \%$ of women and $48.7 \%$ of men have previously received a trauma/emergency or first aid course.

Conclusion: According to this study, it is thought that the medical and dental faculty students who came to the clinical stage of their education had insufficient knowledge about dental trauma, so it would be appropriate to provide dental health information with more comprehensive and understandable way in the education curriculum of the faculties. It will be appropriate to give interdisciplinary seminars, case presentations and lectures on practical emergency response on dental trauma.
\end{abstract}

Keywords: Dental trauma; avulsion; emergency intervention

\section{INTRODUCTION}

Dentoalveolar injuries are considered among the more common traumas, especially in children (1). A literature review from 1995 to 2007 shows that the rates of traumatic dental injury in deciduous and permanent teeth are high worldwide (2). Statistics obtained through independent studies planned in various countries show that one fourth of all school children and almost one third of adults experience trauma related to permanent teeth (3). Although the most common cause is falling, sports, collisions, physical leisure activities, striking an object and traffic accidents are the main causes of traumatic dental injuries (4-6). Data obtained from clinical studies show that the permanent upper central teeth are most frequently affected by dentoalveolar injuries, followed by the upper lateral teeth (7).
Among the dentoalveolar traumas, avulsion has the most severe prognosis. It is defined as the complete separation of the tooth from the alveolar socket due to trauma and it is a serious disorder that constitutes $7.6 \%$ of traumatic dental injuries (8). Avulsion is a complicated type of trauma that affects the periodontal ligaments and alveolar socket as well as affecting the pulp of the tooth (9). The most common period of this type of trauma, which can be encountered regardless of age; It has been recorded in the age range of 8-12 in permanent teeth. The low resistance of periodontal ligaments against incoming extruding forces is explained as the most important reason for the frequency in this age range (10). Following avulsion cases, possible anterior tooth loss in this age group may cause serious psycho-social trauma, functional and aesthetic impairment in children and reduce the quality of life of the individual (11). 
Immediate intervention in avulsion teeth should be done as soon as possible, because the vitality of the tooth and the prognosis of the treatment depend on how the avulsed tooth was handled during first aid and intervention procedures at the time of the accident (12). The prognosis of the tooth and the success of the treatment may vary according to the time spent outside the socket after trauma, where and under what conditions the avulsed tooth is kept, the contamination status, the root development stage of the tooth, the age and systemic status of the individual (13). Fast and appropriate emergency response to avulsion teeth, especially in young children; is very important in terms of ideal long-term prognosis (14). The time spent outside the socket is of great importance for the viability of periodontal ligament cells. Therefore, the ideal emergency response; replanting the avulse into the female socket as soon as possible in the correct form and angle (15). Another issue critical to the vitality of periodontal ligament cells is the environment in which the avulsed tooth is transplanted for treatment. In order to prevent dehydration of the periodontal ligaments, it should be transplanted with solutions such as saline, milk and saliva with appropriate osmolarity and correct $\mathrm{pH}$ value (16). In up-to-date research on suitable transport solutions, HBSS (Hank's Balanced Salt Solution); It has been reported that periodontal ligament cells are viable for up to 72 hours with ideal $\mathrm{pH}$ and appropriate osmolarity, and it is the ideal transport solution that can be used due to these properties (17). Studies on solutions containing current herbal medicaments such as propolis, coconut water and mulberry juice also take place in the literature. Yet, although no evidence of use in Turkey, kits designed specifically for the transport of foreign origin research (Dentosafe ${ }^{\oplus}$, Dentosaf GmbH, Medica, Iserlohn, Germany; EMT Tooth Saveur, I smartpractice. co, Phoenix, AZ, USA) is used and that special It has been reported that the kits preserve cell viability for up to 48 hours and then functional improvement is observed in the teeth (18). Although the milk teeth can be replanted like permanent teeth; In practice, it is not preferred frequently due to the possibility of damage to the permanent tooth germ.

When it comes to the replantation stage in the treatment of avulsed teeth, it is first necessary to remove the foreign materials on the root surface and the blood clot in the socket by washing with water, serum or sterile saline without applying pressure. Following replantation, it should be fixed with a flexible splint for 2 weeks; Afterwards, the patient should be given tetanus vaccine for prophylaxis and systemic antibiotic treatment should be initiated $(19,20,21)$. In avulsion teeth that have completed root development, root canal treatment should be started within 2 weeks after replantation (22).
In teeth with unclosed apex brought in short time and suitable storage conditions; In order to allow revascularization, root canal treatment should not be performed at the first stage, and in case of clinical infection, necrosis or pathological resorption, apexification should be initiated (23). In addition, systemic antibiotics and tetanus vaccine should be administered to the patient $(20,21)$.

In studies conducted in many different countries, the level of awareness and knowledge of dental trauma, especially avulsion, of dentists and non-dentists have been questioned. These studies; Primary school teachers, especially parents, focused on occupational groups that frequently interact with children, such as school nurses, and showed that these groups' awareness and knowledge about dental traumas were insufficient (24-27). Although primary school teachers and parents frequently encounter avulsion, health professionals who intervene and treat avulsion teeth are dentists or emergency service workers. In a similar study conducted in Chile, it was reported that the first place to intervene in traumatic dental injury cases was the hospital emergency services due to the fact that dental clinics working during working hours are not accessible outside of working hours (28). For this reason, it is of critical importance to evaluate the knowledge level and approach of medical physicians who are likely to be applied for the first time in trauma cases. The aim of this study is; To determine the knowledge levels and approaches of the students of Dicle University Faculty of Medicine and Dentistry about traumatic dental injuries.

\section{MATERIAL AND METHOD}

Ethical approval of the study was obtained from Dicle University Faculty of Dentistry Ethics Committee (Date: 27.11.2019, Decision No: 2019/48). All procedures were carried out in accordance with the ethical rules and the principles of the Declaration of Helsinki.

$4^{\text {th }}$ and $5^{\text {th }}$ grade students who continue their education at Dicle University Faculty of Medicine and Dentistry during the 2019-2020 academic year were included in the study. While 150 of the participating students were chosen from the medicine faculty; 150 of them were chosen from the dentistry faculty. Before the questionnaires were applied, the purpose and scope of the study were explained to the participants and their informed consents were obtained; Surveys were then distributed. Data collection forms were distributed to participants who accepted the study and were asked to answer them. The data collection form consists of 17 questions and 3 parts, whose validity and reliability have been tested and used in a similar study published in the literature on the level of knowledge and awareness in the emergency treatment of dental injuries. In the 
first part, the personal information of the participant student was questioned, in the second part, his personal experiences in the face of the situation, and in the third part, his attitudes towards avulsion. The questionnaires were filled out and delivered to us on the same day. In the study, one-to-one face-to-face interview technique was applied. Each participant answered the questionnaire separately. The data obtained in this study were analyzed with IBM SPSS 21 package program. While examining the relationships between groups of nominal variables, Chi-Square analysis was applied. Fisher's Exact Test was used in cases where the expected values in the cells in $2 \times 2$ tables did not have sufficient volume, and Pearson's Chi-Square analysis was applied with the help of Monte Carlo Simulation in $\mathrm{RxC}$ tables. While interpreting the results, 0.05 was used as the significance level; It was stated that there is a significant relationship when $\mathrm{p}<0.05$, and there is no significant relationship when $\mathrm{p}>0.05$.

\section{RESULTS}

The rates regarding gender, faculty and class information of the participants included in the study are shown in Graph 1 and 2 below.

\section{GENDER}

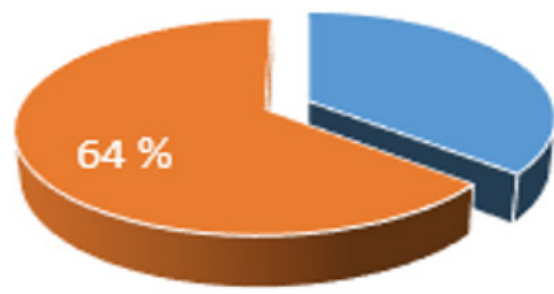

= Woman = Man

Graph 1. Gender distribution plot

\section{Grade Level in Faculties}

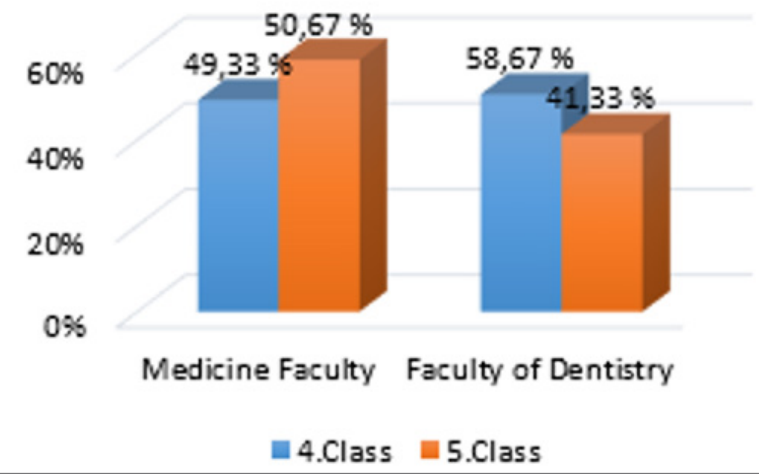

Graph 2. Distribution of regarding grade levels in faculties
The rate of those who previously received trauma/ emergency or first aid course was $39.67 \%$, and the rate of those who did not take a course was $60.33 \%$. The rate of those who have seen tooth injury before is $69 \%$. The rate of those who encounter broken tooth trauma is $66.67 \%$. The rate of occurrence of traumas as a result of falling is $42.51 \%$. Participants in the study stated that when such a situation is encountered, the most appropriate approach is to stop the bleeding at $42 \%$ and search for the tooth.

The appropriate time to get professional help is 39\% 30 minutes. As stated within. The first place to apply for treatment was stated as the faculty of dentistry at a rate of $39.67 \%$. It is stated that if the dislocated tooth is dirty, it will be cleaned by keeping it under tap water for a few seconds without rubbing $56.33 \%$. It has been stated that the dislocated tooth will be held by $68 \%$ of its visible surface and will be preserved in $28.67 \%$ milk environment. The rate of those who can replace the tooth that has been displaced is $45.67 \%$. It is important that $82 \%$ of the tooth that comes out is a milk tooth. The rate of those who can distinguish between milk teeth and permanent teeth is $69 \%$. It was stated that $88.33 \%$ of the milk tooth should not be replaced when it is dislodged

The data obtained in 6 of the questions included in the questionnaire gave statistically significant results with the gender variable $(\mathrm{p}<0.05)$. While $76.6 \%$ of the female participants reported that they had received a trauma/emergency or first aid course before, 51.3\% of the male participants reported that they took this course. While $61.7 \%$ of women answered "yes" to the question in which the condition of seeing tooth injury was questioned before, this rate was reported as $73.1 \%$ for men. While the rate of female participants who stated that the trauma occurred as a result of falling was $57.6 \%$, the rate of male participants remained at $35.5 \%$. $50.5 \%$ of women and $33.7 \%$ of men stated that the first place to apply for treatment is the faculty of dentistry. While $43 \%$ of the women gave the appropriate answer to the question of the environment where the removed tooth will be preserved, the same response rate for men remained at $20.8 \% .78 .5 \%$ of the female participants stated that they could distinguish between the milk female and the permanent female, while $63.8 \%$ of the male participants stated that they could distinguish them.

Considering the faculty variable, the data obtained from 13 questions were found to be statistically significant. $66 \%$ of medical faculty students answered "yes" to the question of "Have you ever taken a trauma/emergency or first aid course?", While this rate remained at $13.3 \%$ for dental students. While $74.5 \%$ of medical faculty 
students and $57.7 \%$ of dental students faced with broken teeth trauma, $36.3 \%$ of medical students and $49.5 \%$ of dental students stated that trauma occurred as a result of falling. $57.3 \%$ of the medical faculty stated that the most appropriate approach when faced with such a situation is to stop the bleeding and search for the tooth, while this rate remained at $26.7 \%$ in the dental faculty. $29.33 \%$ of the Faculty of Medicine and $48.67 \%$ of the Faculty of Dentistry, 30 minutes of the appropriate time to get professional help. stated that it was inside. While $30.7 \%$ of the participants from the medical faculty chose the faculty of dentistry as the first place to apply for treatment, this rate was reported as $48.7 \%$ for the participants from the Faculty of dentistry.

In the case that the tooth that comes out is dirty; $36 \%$ of the medical faculty and $76.7 \%$ of the dentistry faculty stated that they would keep it under tap water for a few seconds without scrubbing, while $59.3 \%$ of the medical faculty students and $76.7 \%$ of the dentistry students stated that the displaced tooth was correct. While 52\% of the dentistry faculty gave the answer to the question

\section{Table 1. Analysis results of the relationship between gender and variables}

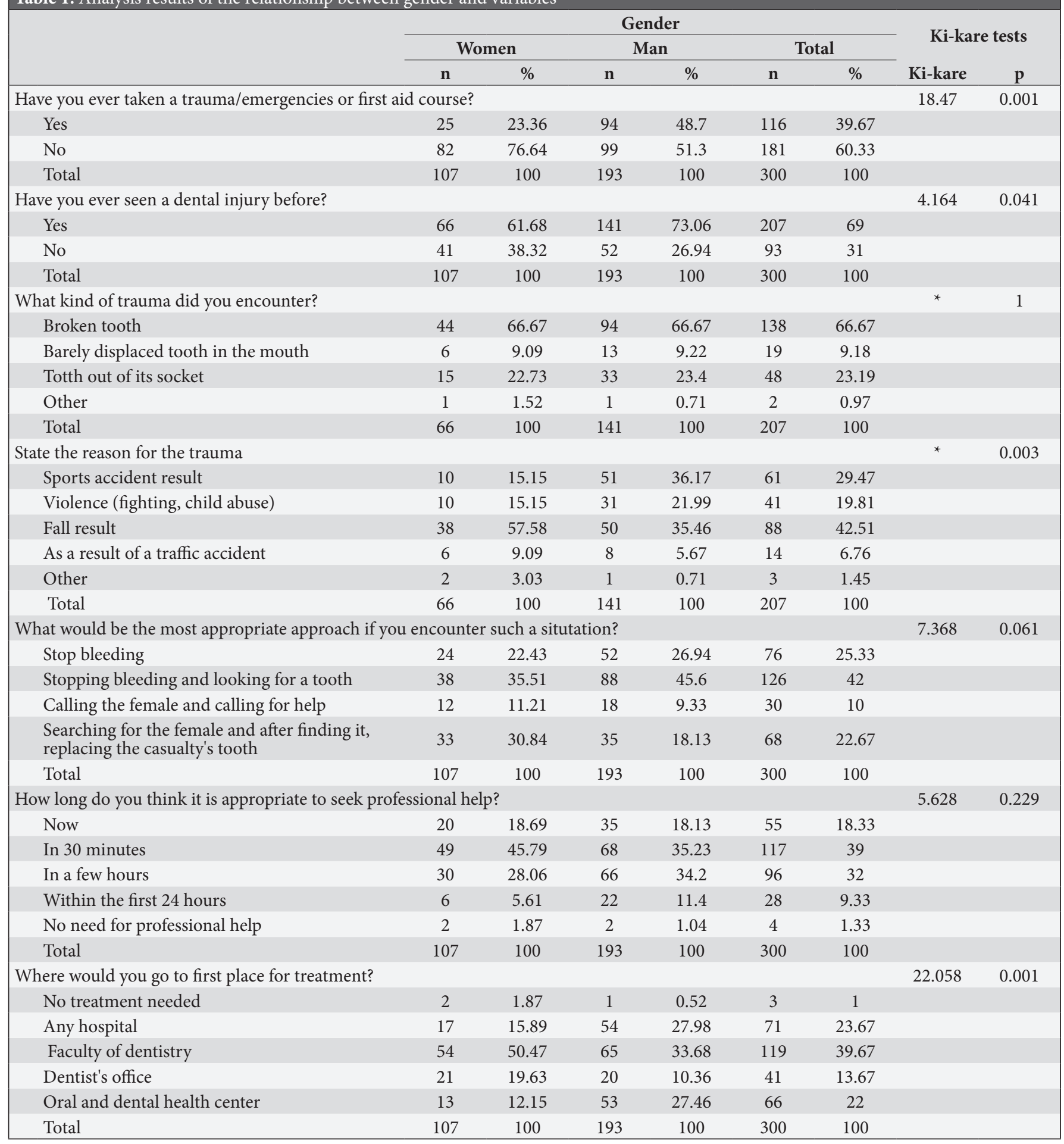


of the environment in which the removed tooth will be preserved, this rate was calculated as only $5.3 \%$ in the medical faculty. While $15.3 \%$ of the medical faculty and $76 \%$ of the dentistry faculty stated that they can replace the tooth that has been displaced, $74 \%$ of the medical school and $90 \%$ of the dentistry faculty stated that it is important that the tooth is a milk tooth. While $99.33 \%$ of the dentistry faculty answered yes to the question we question the distinction between primary teeth and permanent teeth, this rate remained at $38.7 \%$ in the medical faculty. When the milk tooth is displaced, $95.3 \%$ of the medical school and $81.3 \%$ of the dentistry faculty think that the tooth should be replaced.

Statistically significant data were obtained on the class variable in 8 questions in the content of the questionnaire. While $75.3 \%$ of the $4^{\text {th }}$ grade students and $61.6 \%$ of the $5^{\text {th }}$ graders reported having a tooth injury before, $50.8 \%$ of the $4^{\text {th }}$ grade students and $30.6 \%$ of the $5^{\text {th }}$ grade students reported trauma as a result of falling. In case of tooth dislocation, $31.5 \%$ of 4 th grade students answered the question of the most appropriate approach to stop bleeding and search for the tooth, while the rate for $5^{\text {th }}$ grade students was calculated as $54.35 \% .40 .1 \%$ of $4^{\text {th }}$ grade students and $37.7 \%$ of $5^{\text {th }}$ grade students are eligible for professional help. While the rate of $4^{\text {th }}$ grade students who think that the place to apply for treatment is dentistry, $48.8 \%$, the rate of $5^{\text {th }}$ grade students remained at $29 \% .59 .3 \%$ of the $4^{\text {th }}$ grade and $52.9 \%$ of those in the $5^{\text {th }}$ grade, to the question asked about the cleanliness of the dislodged tooth if it is dirty, answered that if the removed tooth is dirty, it will keep it under tap water for a few seconds without rubbing. While $78.4 \%$ of the displaced females in the $4^{\text {th }}$ grade stated that $55.8 \%$ of the $5^{\text {th }}$ grade students would hold the visible surface, the displaced females were replaced by $46.9 \%$ of the $4^{\text {th }}$ grade and $63 \%$ of the $5^{\text {th }}$ grade students.

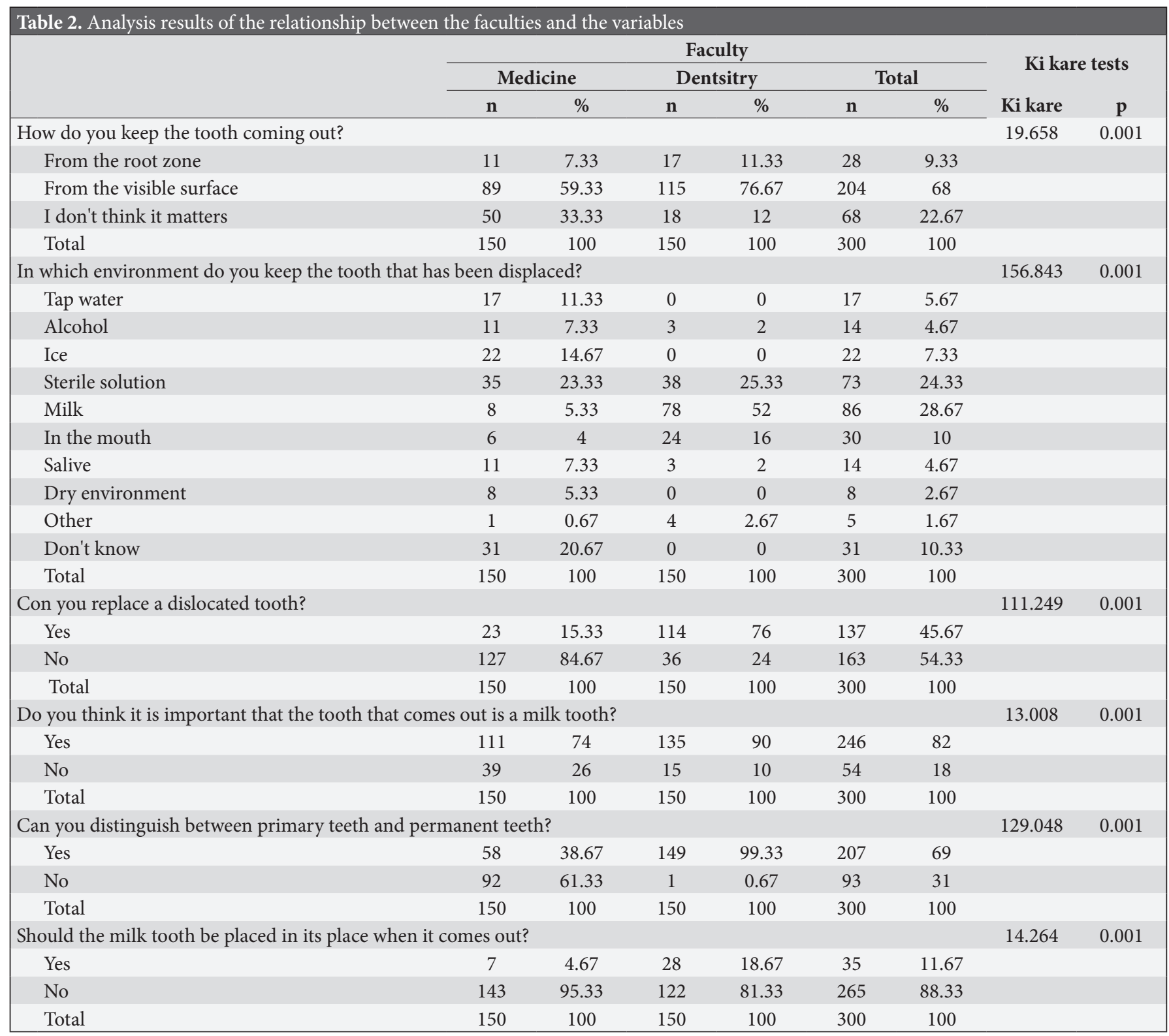


Table 3. Analysis results on the relationship between classes and variables

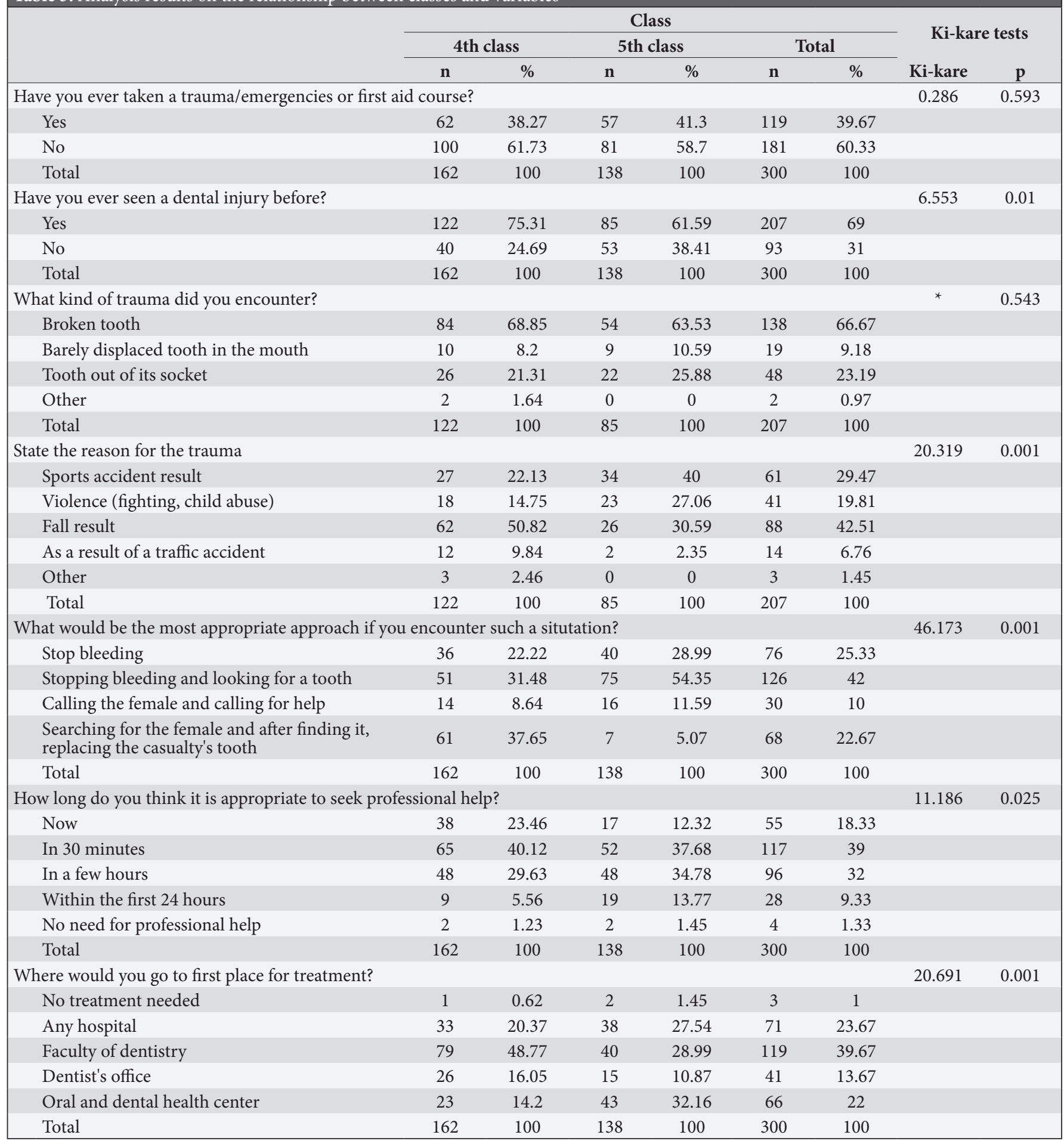

\section{DISCUSSION}

Dentoalveolar injuries, which are the leading oral and dental health problems encountered in our society; It can cause anxiety and pain, especially in children. A mistake that can be made during the correct emergency intervention and appropriate referral can bring along psycho-social problems as well as aesthetic problems. In this sense, dental traumas become one of the serious oral and dental health problems of childhood (29).
Many researchers from different countries have conducted surveys to measure the knowledge levels of various occupational groups about dentoalveolar injuries. Dentists, medical practitioners and dental hygienists are the leading profession groups. Considering the age group encountered, there are studies in which primary school teachers were also included due to these injuries also encountered in schools $(30,31)$.

There are a limited number of studies in the literature that measure the knowledge and awareness levels of medical 
and dental faculty students about dentoalveolar injuries (32). Within the scope of this survey study, it was aimed to determine the awareness of Dicle University Faculty of Medicine and Dentistry students about avulsion, one of the types of dental trauma, and to evaluate their knowledge level regarding treatment protocols.

While $34 \%$ of the medical faculty students and $86.67 \%$ of the dentistry students who participated in our study had not taken a trauma/emergency or first aid course before; $66 \%$ of the medical school and $13.33 \%$ of the dentistry faculty have previously taken a trauma/emergency or first aid course. Similar research conducted in Nepal; $36 \%$ of the students reported that they received training about traumatic injuries (33). Looking at these rates, it can be thought that there are deficiencies in the first aid course and it should be included in the curriculum more.

To the question in which their dental trauma experiences were investigated, $31 \%$ of our participants stated that they have not encountered tooth injury before. In a similar study conducted in Malaysia in 2020, $89.4 \%$ of the students; In another similar publication conducted in Spain in the same year, it was reported that $79 \%$ of the students did not see any dental injuries $(32,34)$. It can be concluded that the history of trauma occurs at different rates regardless of the regions.

Ideal treatment approach for permanent teeth with avulsion is to ensure the replantation of the relevant tooth at the accident site as soon as possible as International Association of Dental Traumatology (IADT)] (35). In this study, $23.46 \%$ of 4 th grade participants and $12.32 \%$ of 5th Grade participants think that the appropriate time to get professional help is immediately. These data are obtained from De Souza Junior et al. As stated in the survey study they conducted on dentistry students in 2020, it corresponds with the students' insufficient level of knowledge about the negative impact of extra alveolar time (36). In Saudi Arabia, 67.5\% of dentistry students answered the question about the ideal replantation time of the tooth correctly (37). This ratio is promising compared to other studies.

In cases where replantation is not possible as soon as possible, avulsed teeth should be stored in a liquid with an appropriate $\mathrm{pH}$ and osmolarity that can preserve the viability of periodontal ligament cells (16). In this study, while $28.67 \%$ of the participants stated that it can be preserved in milk, which is one of the suitable environments, no statistically significant relationship was found between the class variable and the environments where the removed tooth will be kept ( $p>0.05)$. In similar studies, the rates differed according to the classes. In a similar study conducted in Brazil, it was concluded that $50 \%$ of third grade students and 25\% (average
$62 \%$ ) of fourth grade students would use milk as a storage medium until replantation (35). Another study conducted with Dentistry students in Santa Catarina showed that $28.8 \%$ of first-year students and $95.45 \%$ (average 62\%) of graduating students would use milk as a storage medium (38). It was found that the values among dentistry students in Saudi Arabia were higher, and $77 \%$ of the students chose milk as the transport medium for an avulsed tooth (37). In a similar study conducted in Japan, it was observed that the values were lower. $26.4 \%$ of the third grade and $57.4 \%$ of the sixth grade of dental students chose fresh milk as the ideal medium for transplantation (39). Based on these data, it can be concluded that the answers given about suitable transport solutions are insufficient.

The question of how to clean an avulsed tooth if it is dirty, $56.33 \%$ of our participants stated that it will be cleaned by keeping it under tap water for a few seconds without rubbing. According to the 2020 IADT guidelines, this wash is gentle under saline solution or cold running water (32). In a similar study conducted in İstanbul in 2015 , it was concluded that $79.3 \%$ of the students had sufficient knowledge on this subject (40).

There is a statistically significant relationship between the question "Can you replace a dislocated tooth?" and the class variable ( $\mathrm{p}<0.05) .53 .09 \%$ of the 4 th grade students and $36.96 \%$ of the 5 th grade students stated that they can replace the displaced tooth. It has been reported that $75 \%$ of the 4 th grade students and $68.9 \%$ of the 5 th grade students who participated in a similar survey in Malaysia gave a positive answer to this question (32). These rates are in parallel with our study.

"When the primary tooth comes out, can you replace it?" While $11.7 \%$ of our participants answered yes to our question, $88.3 \%$ answered no. In another study conducted in 2014, this question was answered as no at a rate of $86 \%$ (33). The guidelines of the American Academy of Pediatric Dentistry (AAPD) and the International Society of Dental Traumatology (IADT) do not recommend replantation of primary teeth due to the possibility of permanent damage to the permanent tooth germ (41).

The data obtained in our survey study showed that the students did not have sufficient first aid knowledge about dental avulsion and emergency response approaches. In similar studies, it was reported that the information about dental injuries of students was quite insufficient $(42,43)$. In another published study, it was reported that only $8.1 \%$ of medical faculty students had sufficient knowledge of emergency response to avulsed teeth (44). In a similar study conducted in İzmir, it was concluded that the last year medical faculty students had insufficient knowledge about dental trauma (45). 


\section{CONCLUSION}

Oral and dental health is an indispensable element for the individual's social status as well as individual well-being. During childhood, which is a very important period, it is critical to prevent possible dental traumas that may result in aesthetic loss or to overcome the table with the least damage possible with urgent and appropriate intervention in cases encountered.

This survey and literature reviews conducted clearly show that more comprehensive information about oral and dental health should be given in the undergraduate curriculum of the medical schools. Considering the data obtained in this study, it is thought that the medical and dental faculty students who came to the clinical stage of their education had insufficient knowledge about dental trauma, so it would be appropriate to provide oral and dental health information in a more comprehensive and understandable way in the education curriculum of the faculties. In this training, it will be appropriate to give interdisciplinary seminars, case presentations and lectures on practical emergency response on dental traum.

\section{ETHICAL DECLARATIONS}

Ethics Committee Approval: The study was carried out with the permission of Dicle University Faculty of Dentistry Ethics Committee (Date: 27.11.2019, Decision No: 2019/48)

Informed Consent: Because the study was designed retrospectively, no written informed consent form was obtained from patients.

Referee Evaluation Process: Externally peer-reviewed.

Conflict of Interest Statement: The author has no conflicts of interest to declare.

Financial Disclosure: The author declared that this study has received no financial support.

Author Contributions: The author declare that they have all participated in the design, execution, and analysis of the paper, and that they have approved the final version.

\section{REFERENCES}

1. Young C, Wong KY, Cheung LK. Emergency management of dental trauma: knowledge of Hong Kong primary and secondary school teachers. Hong Kong Med J 2012; 18: 362- 70.

2. Glendor, U. 'Epidemiology of traumatic dental injuries-a 12 year review of the literature", Dent Traumatol 2008; 24: 603-11.

3. Livny A, Sgan-Cohen HD, Junadi S. Marcenes W. Traumatic dental injuries and related factors among sixth grade schoolchildren in four Palestinian towns. Dent Traumatol 2010; 26: 422-6.

4. Huang B, Marcenes W, Croucher R, Hector M. Activities related to the occurrence of traumatic dental injuries in 15- to 18 -yearolds. Dent Traumatol 2009; 25: 64-8.
5. Lam R, Abbott P, Lloyd C, Lloyd C, Kruger E. and Tennant M. Dental trauma in an Australian rural centre. Dent Traumatol 2008; 24: 663-70.

6. Fakhruddin KS, Lawrence HP, Kenny DJ, Locker D. Etiology and environment of dental injuries in 12- to 14-year-old Ontario schoolchildren. Dent Traumatol 2008; 24: 305-8.

7. Ersin N, Önçağ RÖ, Ertuğrul F, et al. İlkokul öğretmenlerinin dental travmalarla ilgili bilgi düzeylerinin değerlendirilmesi. Ondokuz Mayıs Üni Diş Hek Fak Derg 2011; 12: 63-8.

8. Donaldson M. and Kinirons MJ. Factor affecting the time of onset of resorption in avulsed and replanted teeth in children. Dent Traumatol 2001; 17: 201-5.

9. Chappuis V. and von Arx T. Replantation of 45 avulsed permanent teeth; A 1-year follow-up study. Dent Traumatol 2005; 21: 289-96.

10. Ozer S, Yilmaz EI, Bayrak S, Tunc ES. Parental knowledge and attitudes regarding the emergency treatment of avulsed permanent teeth. Eur J Dent 2012; 6: 370-5.

11.Cosme-Silva L, Fernandes LA, Rosselli ER, Poi WR, Martins NDS, de Lima DC. Tooth injuries: Knowledge of parents of public school students from the city of Alfenas, Minas Gerais, Brazil, Dent Traumatol 2018; 34: 93-9.

12. Traebert J, Traiano ML, Armenio R, Barbieri DB, de Lacerda, JT, Marcenes W. Knowledge of lay people and dentists in emergency management of dental trauma. Dent Traumatol 2009; 25: 277-83.

13. Raphael S. Parental awareness of the emergency management of avulsed teeth in children. Australian Dent J 1990; 35: 130-3.

14. Al-Jundi SH, Al-Waeili H, Khairalah K. Knowledge and attitude of Jordanian School health teachers with regards to emergency management of dental trauma. Dent Traumatol 2005; 21: 183-7.

15. Pohl Y, Wahl G, Filippi A, Kirschner H. Results after replantation of avulsed permanent teeth. III. Tooth loss and survival analysis. Dent Traumatol 2005; 21: 102-10.

16. Pacheco LF, Filho PFG, Letra A, Menezes R. Evaluation of the knowledge of the treatment of avulsions in elementary school teachers in Rio de Janeiro, Brazil. Dent Traumatol 2003; 19: 76-8.

17. Khademi AA, Saei S, Mohajeri MR et al. A new storage medium for an avulsed tooth. J Contemp Dent Pract 2008; 9: 25-32.

18. Filippi C, Kirschner H, Filippi A, Pohl Y. Practicability of a tooth rescue concept-the use of a tooth rescue box. Dent Traumatol 2008; 24: 422-9.

19. Kwan SC, Johnson JD, Cohenca N. The effect of splint material and thickness on tooth mobility after extraction and replantation using a human cadaveric model. Dent Traumatol 2012; 28: 277-81.

20.Sae-Lim V, Wang CY, Choi GW, Trope M. The effect of systemic tetracycline on resorption of dried replanted dogs' teeth. Endod Dent Traumatol 1998; 14: 127-32.

21. Rhee P, Nunley MK, Demetriades D, Velmahos G, Doucet JJ. Tetanus and trauma: a review and recommendations. J Trauma 2005; 58: 1082-8.

22. Trope M, Moshonov J, Nissan R, Buxt P, Yesilsoy C. Short vs. longterm calcium hydroxide treatment of established inflammatory root resorption in replanted dog teeth. Endod Dent Traumatol 1995; 11: 124-8.

23. Kim SG, Malek M, Sigurdsson A, Lin LM, Kahler B. Regenerative endodontics: a comprehensive review. Int Endod J 2018; 51: 136788 .

24. Hamilton FA, Hill FJ, Mackie IC. Investigation of lay knowledge of the management of avulsed permanent incisors. Endod Dent Traumatol 1997; 13: 19-23.

25. Holan G, Shmueli Y. Knowledge of physicians in hospital emergency rooms in Israel on their role in cases of avulsion of permanent incisors. Int J Paediatr Dent 2003; 13: 13-9.

26. Ghaderi F, Adl A, Ranjbar Z. Effect of a leaflet given to parents on knowledge of tooth avulsion. Eur J Paediatr Dent 2013; 14: 13-6. 
27. Bakır EP, Bakır Ş, Gümüș S, Unal S, Ertuğrul MO. Evaluation of knowledge levels about dental avulsion and treatment of families who have applied to Dicle University. Ejons Int J Math Engineer Natural Sci 2020; 16: 808-16.

28. Díaz J, Bustos L, Herrera S, Sepulveda J. Knowledge of the management of paediatric dental traumas by non-dental professionals in emergency rooms in South Araucanía, Temuco, Chile. Dent Traumatol 2009; 25: 611-9.

29. Namdev R, Jindal A, Bhargava S, Bakshi L, Verma R, Beniwal D. Awareness of emergency management of dental trauma. Contemp Clin Dent 2014; 5: 507-13.

30. Blakytny C, Surbuts A, Thomas A, Hunter ML. Avulsed permanent incisors: knowledge and attitudes of primary school teachers with regard to emergency management. Int J Paediatr Dent. 2001; 11: 327-32.

31. Mesgarzadeh AH, Shahamfar M, Hefzollesan A. Evaluating knowledge and attitudes of elementary school teachers on emergency management of traumatic dental injuries: a study in an Iranian urban area. Oral Health Prev Dent. 2009; 7: 297-308.

32. Mahmood I A, Abg Morshidi D N, Hamzah S H, Baharuddin I H, Ahmad M S, Malaysian dental students' knowledge of managing dental trauma in children. Eur J Dent Educ. 2020; 00:1-6.

33. Limbu S, Dikshit P, Bhagat T, Mehata S; et al. Knowledge of Dental Interns towards emergency management of avulsed tooth in dental colleges in Nepal. J Nepal Health Res Counc 2014; 12:1-7.

34. Valdepeñas J, Adanero A, Martínez E M; et al. Knowledge of dental trauma among dental students. Lecture intervention protocol and follow-up over four academic courses. Eur J Dent Educ 2020; 00:1-8.

35. Fouad AF, Abbott PV, Tsilingaridis G; et al. International Association of Dental Traumatology guidelines for the management of traumatic dental injuries: 2. Avulsion of permanent teeth. Dent Traumatol 2020; 00: 1-12.

36. de Souza Júnior SA, Pavan NNO, Ferreira MLG, Weber I, \& Endo MS. Dental Avulsion: Assessment of dentistry students knowledge in Southern Brazll. SaBios-Revista de Saúde e Biologia 2020; 15: 26-34

37.Al-Shamır1 HM, Alaızarı, NA, Al-Mawerı, SA, Tarakj1 B. Knowledge and attitude of dental trauma among dental students in Saudi Arabia. Eur J Dent 2015; 9: 518-22.

38. Scopel Olıveıra, Pablo, et al. Avaliação do nível de conhecimento sobre avulsão dental de alunos do curso de graduação em Odontologia da Universidade Federal de Santa Catarina. 2014.

39. Fujıta Y, Shıono Y, Makı K. Knowledge of emergency management of avulsed tooth among Japanese dental students. BMC Oral Health 2014; 14: 2-7.

40. Bozatlığlu R, Patır Münevveroğlu A. Tip fakültesine devam eden son sinıf öğrencilerinin travmatik dental yaralanmalara yönelik bilgi ve farkındalık düzeylerinin değerlendirilmesi. J Int Dent Sci 2015; 1:42-6.

41. Anderasen L, Andreasen JO, Day P, et al. International Association of Dental Traumatology guidelines for the management of traumatic dental injuries: 2 . avulsion of permanent teeth. Dental Traumatol 2012; 28: 88-96.

42. Jokic NI, Bakarcic D, Grzic R, et al. What general medicine students of University of Rijeka know about dental avulsion? Eur J Dent Educ 2017; 21: 131-4.

43. Bakır EP, Bakır S, Gümüs S, Sonkaya E. Evaluation of the knowledge of first-and second-year medical and dental students regarding dental trauma (avulsion) and treatment approaches. Analytical And Quantitative Cytopathology and Histopathology 2021; 43: 19-26.

44. Oleszkiewicz I, Emerich K. How to proceed in case of tooth avulsion: state of student knowledge. Eur J paediatrv Dent 2015; 16
45.Eden E, Kılınç G, Ellidokuz H. İzmir ilindeki iki tıp fakültesine devam eden son sınıf öğrencilerinin dental travmaya yaklaşımları. DEÜ Tip Fakültesi Derg 2011; 25: 31-7. 